$\begin{gathered}\text { EPiC Series in Education Science } \\ \text { Volume 1, 2017, Pages 129-138 }\end{gathered}$
$\begin{gathered}\text { AUBEA 2017: Australasian Universities Build- } \\ \text { ing Education Association Conference 2017 }\end{gathered}$

\title{
MEETING CHANGING INDUSTRY EXPECTATIONS FROM AUSTRALIAN PROPERTY VALUATION GRADUATES
}

\author{
D. Halvitigala ${ }^{1}$, S. Wilkinson ${ }^{2}$, H. Antoniades ${ }^{3}$ \\ ${ }^{1}$ Senior Lecturer, RMIT University \\ $2 \& 3$ Associate Professor, University of Technology Sydney \\ dulani.halvitigala@rmit.edu.au
}

\section{ABSTRACT}

The valuation profession faces significant challenges as more valuation processes become automated, and the role of the valuer becomes more one of data handling than an economic analyst. To respond to industry needs, the role of the valuer must change. It follows that there is a need for universities to re-evaluate their existing property curricula, modifying content where necessary, to prepare their graduates better for a changing workforce. Employing a series of focus group discussions with valuation practitioners, this study examined specific industry expectations and provides recommendations to strategically align Australian property curricula with industry expectations in order to maintain the relevance of property education.

The study identified personal, technical and business-related skills that are essential for graduates to possess. The roles of the professional bodies, industry/employers and educators to meet the changing demand on the profession are identified. Changes are required to degree programme content in respect of digital technologies and statistical skills. Whilst the universities offer a curriculum that adheres to the accreditation requirements of the professional bodies, there is also a need to

incorporate specialised knowledge with set pathways. The need for students to have practical experience is apparent and undertaking placements with assessment that could be credited as part of the degree is recommended. The study highlights the need for a careful analysis of student learning 
experience to ensure that graduate skills meet the industry expectations, and that graduates themselves are able to adapt to future changes.

Keywords: Curriculum, Employability skills, Property valuation industry, Tertiary education

\section{Introduction}

It is said that we are on the precipice of great change as a result of digital technologies and many professions globally including law, built environment, construction, property and surveying are endeavouring to comprehend what these changes might mean to their professional bodies and also to their members (Susskind and Susskind, 2015; RICS, 2015). In Australia, the valuation profession too faces significant challenges, for example, as more valuation processes become automated, and the role of the Valuer transitions to more one of data handling than economic analysis. In order to respond to market and industry needs, the role of the Valuer must, inevitably, change.

It follows therefore that education providers such as universities will need to reassess existing property curricula, and to modify them where necessary, in order to prepare their graduates better for a changing work experience. This paper sets out the context and rationale for change, along with the predicted knowledge fields and skills deemed increasingly important to perform well in the future world of the built environment professional.

The research design and approach are described. This qualitative study adopted a series of focus group discussions with valuation practitioners. The aim being to examine specific industry expectations from valuation graduates and to provide recommendations to strategically align Australian property curricula with industry expectations in order to maintain the relevance of property education.

The personal, technical and business-related skills that are essential for graduates to possess are presented in the results and analysis section of the paper. The roles of the professional bodies, industry/employers and educators to meet the changing demand on the profession are identified. In addition the changes required to degree programme content in respect of digital technologies, statistical knowledge and skills are also highlighted. Furthermore, the issue of new, and/or, adapted pathways to membership in the professional bodies is evaluated. Future needs in respect of practical work experience for students are also examined. The conclusion and further study highlights the need for a careful analysis of student learning experience to ensure that graduate skills meet industry expectations, and that graduates are adaptable and flexible in respect of inevitable future changes in the workplace. 


\section{Literature review}

The rapid growth in information and communication technology (ICT), coupled with the globilisation of businesses, has provided an explosion of data availability from different sources. For instance, digital technologies and artificial intelligence (AI) pose significant threats to the existing valuation practice. Many of the steps in the valuation process - data collection, data analysis and data formatting are performed by computerised models and the valuation profession is moving towards automated processes (Grover 2016). In Australia, this is evidenced by companies such as CoreLogic, APM Price Finder and Monitor, all offering computer generated valuation reports, which have been developed to allow for rapid, cost-effective outputs. The computer generated automated valuation models (AVMs) use one or more mathematical models, including regression, adaptive estimation, neural networks or an artificial intelligence program, to estimate the value of a property or series of properties (RICS 2016). Unfortunately the conventional valuation methods do not emphasise mathematical and statistical applications (Silva, 2014). Therefore, typical Valuers may struggle with the use of these models and in the future, the mortgage industry will require Valuers who are

'supported by analytics' (Schneider, 2016).

Other technology based applications includes blockchain systems for mortgage valuations (Taft, 2016). Blockchain systems contain a list of data records that are organised into a series of blocks, each containing a batch of records of transactions. The benefits for the banking sector to integrate blockchain into their mortgage valuations are the reduced regulatory requirements (Weinland, 2016). Once the database is formulated property purchases can be streamlined with less reliance on mortgage valuations from Valuers. It is envisaged over the next few years, the industry will transform from the art of appraising to the science of appraising (Bradford, 2014). Therefore, the profession must embrace these technological changes as a strategic partner, in other words, as a positive addition rather than a threat (Robson and Downey, 2010).

It is no longer the availability of data and market knowledge that differentiate Valuers. It is in fact what they do with the data that differentiates them from their counterparts. Therefore, the role of the valuer is increasingly moving towards being an information analyst from being an information gatherer. However it is not only the Valuers who must change, but also the content of educational programs. For instance some skills and knowledge have faded in importance and are declining. Today's professional need to be outcome focused, with good oral and digital communication skills, and posses advanced problem solving skills to deal with complex issues. Because there is no simple solution complex issues are sometimes known as 'WICKED problems' (Bright et al, 2016).

Therefore, advanced problem solving skills should be embedded within educational programmes. Most likely complex problems will involve inter- 
disciplinary and trans-disciplinary approaches embracing a collaborative methodology. Other skills could also include the ability to evaluate all possible options and to select the best course of action. Concurrently there is also the potential to generate new avenues for value creation from the vast amounts of data now available from real estate. The growth in property trusts and similar investment opportunities

have meant that a valuer needs to have a totally different skill-set in order to undertake valuations for these portfolios (Elliott and Warren, 2005). All practicing valuers should be conscious of the changing business environment and the need to strengthen their skills and must be forward-thinking to survive in this new era of globalisation.

Additionally knowledge fields Valuers will need in the future, includes sustainability and how this impacts on value, risk management, upgrading existing skills of data analysis, embracing digital technologies and artificial intelligence. With up to four generations now in the workforce, professionals need greater leadership skills to ensure optimum productivity and quality of outputs. Finally professionals, corporations and professional institutions should posses inherent ethical behaviour.

Education has a vital role in the way forward and 'the relationship between the professional bodies and universities, government and other stakeholders is, therefore critical if the professions are to emerge as reflective as well as responsive to the issues and expectations of the $21^{\text {st }}$ Century' (Hughes and Hughes, 2013). In this regard the profession faces challenges because of the different criteria to measure the eligibility of Valuers, within the various professional bodies. The need for those organisations to unite behind common standards for education, behaviour, service delivery, monitoring and regulation are emphasised in order to mitigate the risks arising from a lack of a clear identity for the profession as a whole (Thorne, 2012).

Employees, in general, and including Valuers, will need to embrace change and become more entrepreneurial, and there is scope and potential for these entrepreneurial skills to be included in education programmes. Research predicts that the workforce will have more freelancers or contracted staff who work for multiple employers. This indicates the valuation professions may need to move from honing one particular narrow skill set and develop a broader, adaptable and flexible skill set (Susskind and Susskind, 2015). In some sectors social entrepreneurship and projects involving social good will become

increasingly important and redefine employment opportunities and there may be opportunities available for some Valuers.

In conclusion it is the responsibility of the practitioners, professional bodies and educators to embrace changes that market and technological advances 
bring to the profession and lift the professionalism of the practice so that the valuation industry will continue playing a vital role in the economy.

\section{Research Methodology}

Due to the exploratory nature of this research, an inductive qualitative approach was the most appropriate research methodology (Silverman, 2013). Qualitative research has a preference for qualitative data with the analysis of words and images rather than numbers, featuring observation rather than experiment, and semi and unstructured interviews rather than structured interviews. Qualitative research is particularly important when prior insights about the phenomenon under scrutiny are modest (Ghauri and Gronhaug, 2005), which is the case in this study. The need to gather as large a number of views as possible, at a deep and rich level, and; in a short space of time, meant that focus groups were the most cost effective and expedient means of gathering data (Robson, 1993).

The focus groups aimed to canvass as much opinion as possible from the parties most closely involved in the practice of valuation in Australia, i.e. Australian Property Institute (API) members. The API announced the research via an email and newsletter to all members, who were invited to contact the researchers if they wished to participate in the study. Following expressions of interest, participants were invited to attend the focus group sessions hosted at the University of Technology Sydney (UTS) in Sydney, and the Royal Melbourne Institute of Technology (RMIT) in Melbourne and the focus groups were convened over a 2-3 hour period. Twenty five valuation practitioners participated in the focus group discussions, comprising fifteen individuals in Melbourne and ten in Sydney. They were chosen on the basis of their speciality area in valuation, length and type of experience of valuing different

property types, nature of the organisation they worked for and their seniority within the organisation. The participants specialised in various areas in valuation including residential, commercial, plant and machinery, agribusiness, asset, going concerns, government, and specialist property valuations. All the participants were industry experts who were content matter experts within their respective fields and regularly engaged in providing professional valuation services to clients.

\section{Results and discussion}

Focus group participants were asked to identify new knowledge and skills required for the future of the valuation profession and how the current property curricula should be changed to prepare their graduates better for a changing workforce. Table 1 summarises the new knowledge and skills required from future Valuers and what educators can do to ensure these skills are taught to 
produce 'job ready' graduates. The scope was fairly broad and participants covered themes such as educational requirements, specialised

knowledge base, technology and the requirement for other industries to be aware of the exact nature and purpose of property valuations.

Table 1: The role of educators to meet future challenges

\begin{tabular}{|c|c|}
\hline $\begin{array}{l}\text { New knowledge and skills } \\
\text { competency required }\end{array}$ & Actions for educators \\
\hline $\begin{array}{l}\text { More practical experience } \\
\text { before graduation. }\end{array}$ & $\begin{array}{l}\text { - A component of practical experience as } \\
\text { part of the degree. } \\
\text { - Graduates need to be taught how to do } \\
\text { a 'speaking valuation'. } \\
\text { - Offer more scholarships for } \\
\text { postgraduate students to do research } \\
\text { on practical and important issues. }\end{array}$ \\
\hline Data / big data analysis. & $\begin{array}{l}\text { Introduce courses on advanced data } \\
\text { analysis techniques in valuation. }\end{array}$ \\
\hline $\begin{array}{l}\text { Practice management \& } \\
\text { business development skills. }\end{array}$ & - Offer short training courses. \\
\hline $\begin{array}{l}\text { Specialisation in a few areas of } \\
\text { valuation rather than just one } \\
\text { area. }\end{array}$ & $\begin{array}{l}\text { - } \quad \text { Provide more emphasis on different } \\
\text { specialist areas (rural, plant and } \\
\text { machinery, business, aged care and } \\
\text { retirement living, REITs in teaching }\end{array}$ \\
\hline $\begin{array}{l}\text { Valuation advice should be } \\
\text { beyond just 'point estimates'. }\end{array}$ & $\begin{array}{l}\text { - Need to broaden the scope of valuation } \\
\text { by introducing sensitivity analysis, } \\
\text { scenario analysis, statistical inferences, } \\
\text { risk pricing etc. into valuations }\end{array}$ \\
\hline $\begin{array}{l}\text { Develop more inter-disciplinary } \\
\text { skills. }\end{array}$ & $\begin{array}{l}\text { - Some universities currently limit the } \\
\text { scope to meet the needs of the API. } \\
\text { Students should learn from other } \\
\text { disciplines' problem solving approaches } \\
\text { and skills. }\end{array}$ \\
\hline $\begin{array}{l}\text { Develop greater market } \\
\text { forecasting skills and better } \\
\text { awareness of property cycles } \\
\text { and forecasting trends. }\end{array}$ & 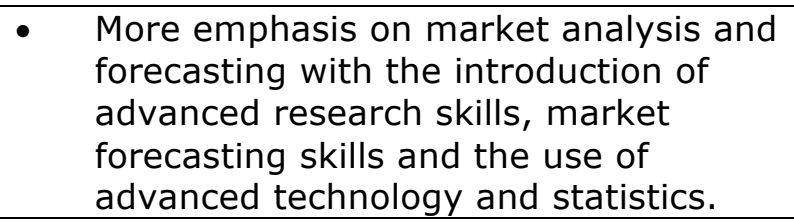 \\
\hline $\begin{array}{l}\text { Students should be able to } \\
\text { identify the specialist area in } \\
\text { property, in which they are } \\
\text { interested, earlier in degree } \\
\text { programmes. }\end{array}$ & $\begin{array}{l}\text { - Universities go too long without giving } \\
\text { students the opportunity to decide if } \\
\text { they want to be valuers. Universities } \\
\text { should provide sufficient information } \\
\text { for students to make career choices } \\
\text { earlier in their studies. }\end{array}$ \\
\hline $\begin{array}{l}\text { Better understanding of local } \\
\text { conditions. This is often less } \\
\text { understood than valuation }\end{array}$ & $\begin{array}{l}\text { - Increase more focus into local market / } \\
\text { context. } \\
\text { - Increase focus on work ethics, relevant }\end{array}$ \\
\hline
\end{tabular}




\begin{tabular}{|c|c|}
\hline theory. & $\begin{array}{l}\text { government codes, standards and } \\
\text { regulations. }\end{array}$ \\
\hline $\begin{array}{l}\text { To be able to provide reality } \\
\text { based outputs than models } \\
\text { (theory based). }\end{array}$ & $\begin{array}{l}\text { Get more industry personnel involved } \\
\text { and maintain regular contact and } \\
\text { dialogue with industry (e.g. guest } \\
\text { lectures, industry days, site visits, } \\
\text { mentoring, personal counselling and } \\
\text { guidance). }\end{array}$ \\
\hline Better data collection skills. & $\begin{array}{l}\text { - Have more assessments examining } \\
\text { students' research and data collection } \\
\text { skills. }\end{array}$ \\
\hline Better data analysis skills. & $\begin{array}{l}\text { - Include courses that focus on advanced } \\
\text { data analysis techniques related to } \\
\text { valuation. }\end{array}$ \\
\hline Technical skills. & $\begin{array}{l}\text { - Include technology, application of } \\
\text { software into valuation teaching (e.g. } \\
\text { measuring, sketching, valuations, GIS } \\
\text { for mapping and location analysis). }\end{array}$ \\
\hline $\begin{array}{l}\text { Advisory, communication, team } \\
\text { and interpersonal relationship } \\
\text { skills. }\end{array}$ & $\begin{array}{l}\text { - Offer public speaking opportunities to } \\
\text { students, in the classroom and in } \\
\text { formal presentations. } \\
\text { Better training on core business, } \\
\text { economic principles, advocacy, } \\
\text { marketing and 'people skills'. } \\
\text { Offer short training courses focusing } \\
\text { developing personal skills. }\end{array}$ \\
\hline $\begin{array}{l}\text { Plant and machinery } \\
\text { valuations. }\end{array}$ & $\begin{array}{l}\text { - Include plant and machinery courses in } \\
\text { to some property degrees, as this is } \\
\text { not currently taught in the Australian } \\
\text { context. }\end{array}$ \\
\hline $\begin{array}{l}\text { More emphasis on rural } \\
\text { valuations, }\end{array}$ & $\begin{array}{l}\text { - More courses should be offered as } \\
\text { there is a great demand for rural } \\
\text { valuations. }\end{array}$ \\
\hline $\begin{array}{l}\text { Consistency in the content } \\
\text { covered in property degrees. }\end{array}$ & $\begin{array}{l}\text { - University of Melbourne, RMIT and } \\
\text { Deakin offer different courses, course } \\
\text { duration and learning outcomes to } \\
\text { achieve the same end. Similarly in } \\
\text { NSW, UTS and Western Sydney } \\
\text { University and Sydney Institute of } \\
\text { technology (S.I.T), offer different } \\
\text { courses but with similar end } \\
\text { qualifications. }\end{array}$ \\
\hline
\end{tabular}

Focus group participants consistently identified several important skills necessary for graduates to possess if they were to achieve career success, adding value to the valuation profession. They can be mainly categorised into personal skills (advisory, communication, team, organisational, interpersonal 
relationship skills), business related skills and technical skills. Recommendations were made that more written and oral requirements should be included in the property curricula and that universities could offer short courses to improve students' personal skills. It was strongly recommended that business skills such as practice management and business development should be included in undergraduate courses. Furthermore participants repeatedly emphasised the necessity of possessing sound technical skills for property graduates and the requirement of including advanced computer skills, data collection and advanced data analysis skills in the curricula and student assessments.

Another major theme emerging is the lack of applied practical skills with the theoretical context delivered at universities. Several participants were of the opinion that new graduates are too focused on employing 'text book' solutions with simplified assumptions to solve problems and lack real-world, creative problem solving skills. The need for students to have practical relevant work experience was apparent and the possibility of undertaking placements with some assessment that could be credited as part of the degree, which is a model adopted extensively in other countries such as the UK, is recommended. Whilst the universities should aim to produce more "job ready" graduates, the professional bodies are required to provide assistance with industry involvement. Educators were encouraged to provide more real-world applications, put strong emphasis on case studies as part of the learning, maintain strong industry interaction by utilising their expertise and resources by way of guest lectures, industry days, site visits, mentoring and counselling programmes.

Furthermore, there has been great emphasis on the shortage of skilled knowledge in specialist areas such as plant and machinery, rural, aged care and retirement living valuations and the valuation of large portfolios such as Real Estate Investment Trusts (REITs). The industry perceived that these areas are not sufficiently taught currently and therefore emphasised the importance of including them in the curricula or introducing

short courses to cover these emerging specialist areas. In conflict with this skills shortage is the current educational curricula which do not offer clear pathways for graduates to specialise (or to undertake a "sub-major" as part of their undergraduate degree), and the very obvious varying property courses offered nationally, but with the same end result qualification and recognition from the API. The professional bodies need to assist the educational providers to source practitioners with these specialised skills who would be able to help prepare resource notes, guidance with assessment tasks, and undertake lectures as required. In addition, the necessity of broadening the scope of valuation was emphasised and the introduction of alternative valuation products such as broad market analyses, accurate value predictions, and risk pricing into students' learning experience was recommended.

However, these items discussed above cannot be solved in isolation and require a unified approach from both the professional bodies and the educational 
institutions, and a deeper awareness from industries interlinking with the property professional. Whilst the universities offer a set curriculum that adheres to the accreditation requirements of the professional bodies, there is also the need to incorporate specialised knowledge and skills with set pathways. This would provide a very good defined career approach for the future of the property professional. For this to happen, it is necessary for the professional bodies to forge industry partnerships and provide assistance to the educators. The assistance would include access to resources and skilled people who are able to become involved in the development and delivery of specialised topics, plus opportunities for graduates to obtain practical experience. In conclusion, valuers, professional bodies and educators collectively need to advance the professionalism of the valuation practice. In other words, the role of valuers should be changed from simply being 'point in time experts' to a service which the market and clients perceive as adding value to the business process and for which they are prepared to pay a fee worthy of the expertise of the valuation professional.

\section{Conclusions and further research}

In facing significant challenges including automation of valuation processes, and the role becoming more one of data handling than an economic analyst, the Valuation profession needs to adapt to survive and thrive. In order to prepare new entrants to the profession, universities need to reassess existing property curricula modifying them where necessary, to prepare graduates better for a changing workforce. Using focus groups with valuation practitioners, this study examined industry expectations from valuation graduates and identified steps to strategically align Australian property curricula with industry expectations to ensure education remains relevant.

The research identified personal, technical and business-related skills deemed essential for graduates. The respective roles of the stakeholders; professional bodies, industry, employers and educators to meet the changing demands are evaluated. Changes are needed to degree programme content in respect of digital technologies and statistical knowledge and skills. Whilst the universities offer a curriculum that aligns with professional body accreditation requirements, there is a need to incorporate specialised knowledge and skills. Students need practical experience and undertaking industry placements with assessment that is credited as part of the degree is recommended; the UK sandwich degree model. The study highlights the need for a careful analysis of student learning experience to ensure that graduate skills continue meet evolving industry expectations and that graduates are flexible and adaptable to inevitable future changes.

\section{References}

Bradford, J. (2014). 'Appraising: At the crossroads of art and science', Mortgage Banking, Vol. 74(8), pp. 100 - 101.

Bright, S., Patrick, J., Thomas, B., Bailey, E., Janda, K. B., Dixon, T. \& Wilkinson, S. (2016) 'The evolution of green leases: towards inter-organizational 
environmental governance', Building Research and Information, Vol. 44(5/6), pp. $660-674$

Elliott, P. and Warren, C.M. (2005). 'The valuation profession in Australia: Profile, analysis and future direction', 11th Pacific Rim Real Estate Society Conference, Melbourne 24-27 January.

Ghauri, P. and Gronhaug, K. (2005). Research methods in business studies, a practical guide (3rd ed.). New York: Financial Times Prentice Hall.

Grover, R. (2016). 'Mass valuations', Journal of Property Investment \& Finance, Vol. 34(2), pp. 191-204.

Hughes, W., and Hughes, C. (2013). 'Professionalism and professional institutions in times of change', Building Research and Information, Vol. 41(1), pp. 28-3.

RICS (2016). 'Automated Valuation Models (AVMs) - Opportunity or Threat?', RICS, London.

Robson, G. \& Downie, M.L. (2010). 'Integrating submarket valuation models with valuation services to meet the needs of Victorian borrowers, lenders and Valuers', Royal Institution of Chartered Surveyors.

Robson, C. (1993). Real World Research: A resource for social scientists and practical researchers, Oxford, UK

Schneider, H. (2016). 'Recapturing the art of appraising', Mortgage Banking, April, pp. 30-31.

Silva, J. (2014). 'The ideal world of valuations', Mortgage Banking, Vol. 74(6), pp. $96-97$.

Silverman, D. 2013. Doing Qualitative Research. A Practical Handbook. Sage Publications, London.

Susskind, R. and Susskind, D. (2015). The future of the professions: How technology will transform the work of human experts, Oxford University Press, USA.

Taft, D. (2016). 'Blockchain moving beyond finance; still in early stages', eWeek, http://www.eweek.com/cloud/blockchain-moving-beyond-finance-still-inearly-stages, viewed: 10 December 2016.

Thorne, C. (2012). 'Valuation: the professional challenge', Journal of Property Investment \& Finance, Vol. 30(4), Editorial.

Weinland, D. (2016). 'Banks adopt blockchain for mortgage valuation system', Financial Times, https://www.ft.com/content/c856787c-9523-11e6-a1dcbdf38d484582, viewed: 10 December 2016. 